\title{
Technology Adaptation, Innovation Resistance and Net-Banking Behavior among Middle Aged Adults
}

\author{
Dr. Mini TC \& Dr S.T. Janetius \\ Dr. Mini TC, Associate Professor, Institute of Management, Christ University, Bangalore \\ Dr. S.T. Janetius, Director, Centre for Counselling and Guidance, Sree Saraswathi Thyagaraja College, \\ Pollachi
}

\begin{abstract}
Middle age is a period between young adulthood and old age. Psychologists have defined specific characteristics for this group of adults who are in the making of their own person. Unlike the EPIC generation (Fadul, 2010), it is generally agreed that the middle aged people are poor in technology adaptation. Innovation resistance therefore can place them in a disadvantageous position in the society. The phenomenal technology boom in India in the last two decades have initiated internet and online banking and banks started offering clientele services in a more competitive way. How far the middle aged adults have adopted this technology and live in tune with the modern trends is an unexplored area.

Do all the middle aged consumers have adopted themselves to internet banking and the associated new technology; what are the reasons for utilizing net-banking and also innovation resistance - are the main focus of this study. The subjects of this exploratory study are middle aged adults (aged 40 to 60) from Pollachi region in Tamil Nadu. Convenient sampling was used to collect data. The data was analyzed using Innovation Resistance theory (Ram \& Sheth, 1989) and the Technology Acceptance Model (Venkatesh \& Davis, 2000) to identify online banking behavior.
\end{abstract}

\section{The Review:}

\section{Introduction}

Studying the behavior pattern of middle aged adults is relatively a recent phenomenon. In the beginning of $20^{\text {th }}$ century, the average life expectancy was less than 50 years. After the advent of technological developments in the field of medicine, lifestyle has changed considerably and psychologists started to focus on the various stages of human development. Thus, studies on middle adulthood started to gain considerable importance. Although there is no consensus among scholars on the chronological age brackets of middle adulthood, 40-60 is the popular understanding. During this period, many changes have been identified: the most notable changes occur in physical condition and health, career development and finance management, marriage and parenting and, leisure time activities. Psychologists generally believe midlife as a period of defining one's own self and achieving maturity towards self-actualization (Janetius, 2012). Corey (1986) and Levinson (1978) who have made extensive research in the field of midlife conclude that a more rigid life style is commonly seen among adults in midlife. In this regard, it is worth studying the middle adulthood population and to know their adaptation strategies to modern day technology as well as their innovation resistance.

The arrival of internet has changed the nature of communication in every sphere of daily living. Due to the inevitable nature of its usage, financial institutions drive consumers and businesses to change their traditional modes of operation and adopt one or other way the modern trend (Gardener et al.1999). As a result, the financial services have become easier to access and transact and, banking institutions use it lavishly and competitively in attracting clients.

Net-banking or online banking as it is popularly known has emerged as one of the most cost-effective banking applications over the last decade. Gone are the days in which people queue up on Mondays in front of the banks to make financial transactions after a weekend closure, and wait for a new month to begin to get their salary and pay bills. Today any financial transaction could be done on mobile and at homes $24 \times 7$. ATMs, credit cards and debit cards have made purchase and pay easier than ever. The different modes of service delivery channels through which consumers can interact with the banks have increased tremendously these days and made life more easier than couple of decades ago. No bank can survive today without offering ATMs, debit and credit cards, internet and other wireless banking services even in small towns and villages.

The present day younger generation that is born and brought up in the modern technology, often labeled as "EPIC" because of its peculiar characteristics of experiential, participative, image-driven, and connected (Fadul, 2010), is very much familiar with the net-banking and other online services. On the other hand the middle aged people are introduced to the mobile and internet technology in the recent past and therefore it is an obvious fact that not all of them are familiar and utilizing these modern facilities. We can identify two theoretical bases for this phenomenon: i) Innovation resistance and ii) Technology adaptation. 
Some customers resist innovations either because it poses potential changes from a current satisfactory status quo or because it conflicts with the consumer's belief structure (Ram \& Sheth, 1989). Innovation resistance is also determined as 'a preference for existing, familiar behaviors over novel ones' and is often considered as a special form of resistance to change (Arnould et al. 2004).

The Technology Acceptance Model (TAM) introduced by Davis (1986) is one of the most cited theoretical frameworks to understand and predict the process of user acceptance and adoption of new technology. The users come to accept and adopt a technology mainly due to the perceived usefulness that is the degree to which a person believes that using a particular system would enhance his or her task performance and also perceived ease-of-use that is, the degree to which a person believes that using a particular system would be free from effort (Venkatesh \& Davis 2000). Perceived usefulness directly influences the intention to use the new technology, whereas the perceived ease of use has an indirect effect through perceived usefulness and attitude on the behavioral intention.

\section{Objectives:}

The objectives of this exploratory study are twofold. First it explores whether all the middle aged consumers have adopted internet banking. Secondly the study identifies the reasons for utilizing net-banking and reasons for resistance and non-use.

\section{Methodology:}

The subjects of this exploratory study are 245 middle aged adults (aged 40 to 60) from Pollachi region of Tamil Nadu. Convenient sampling was used to select subjects for this study. A multiple option interview questionnaire was used to collect data. The data was analyzed using Innovation Resistance Theory (Ram \& Sheth, 1989) and the Technology Acceptance Model (Venkatesh \& Davis, 2000) to identify net-banking behavior.

\section{Results:}

The sex of the study population was almost equally divided (male $49 \%$ and female $51 \%$ ) and their educational qualification range from high school to postgraduate college studies. None of the subject was uneducated. Nearly $40 \%$ of the respondents were diploma holders or high school graduates. Nearly $54 \%$ of the subjects were college graduates and $6 \%$ education graduates.

Table 1: Showing sex, age and educational background of respondents

\begin{tabular}{clcc}
\hline & & $\begin{array}{c}\text { Number } \\
\mathbf{N = 2 4 5}\end{array}$ & Percentage \\
\hline \multirow{3}{*}{ Sex } & Male & 121 & $49.38 \%$ \\
& Female & 124 & $50.62 \%$ \\
\hline \multirow{5}{*}{ Education } & & \\
\hline & High school & 70 & $28.57 \%$ \\
& Diploma & 28 & $11.42 \%$ \\
& UG College & 88 & $35.91 \%$ \\
& PG and Above & 45 & $18.36 \%$ \\
& BEd or MEd & 14 & $5.71 \%$ \\
& & & \\
\hline \multirow{5}{*}{ Age } & $40-45$ & 83 & $27.34 \%$ \\
& $46-50$ & 67 & $21.63 \%$ \\
& $51-55$ & 53 & $17.14 \%$ \\
\hline
\end{tabular}

As per the overall banking tendency of the respondents, only $9 \%$ of them use banking services very rarely where as $4 \%$ use it very often. Nearly $71 \%$ of them use banking services on a monthly basis and $16 \%$ weekly.In spite of the fact that all the 245 subjects studied are educated and nearly $72 \%$ of the subjects are diploma holders, graduates from college or from educational field, it is amazing to know that nearly $77 \%$ of the of them do not use net-banking services. Only $23 \%$ of them use this modern technology. Among the postgraduates, only $40 \%$ use net-banking and online banking technology.

As per the reasons for choosing a particular bank or opening an account in a bank, only 5\% of the subjects choose a specific bank for the sake of online banking. Majority of the subjects prefer better customer service and some people prefer a bank that is close to home or office or easy to access. Nearly $28 \%$ of people do not have personal preference for a bank. 
Table 2: Showing general banking behavior of respondents

\begin{tabular}{|c|c|c|c|}
\hline & & $\mathrm{N}=245$ & Percentage \\
\hline $\begin{array}{l}\text { Banking } \\
\text { Behavior }\end{array}$ & $\begin{array}{l}\text { Very Often } \\
\text { Weekly } \\
\text { Monthly } \\
\text { Very rarely }\end{array}$ & $\begin{array}{c}9 \\
39 \\
175 \\
22\end{array}$ & $\begin{array}{c}3.67 \% \\
15.91 \% \\
71.42 \% \\
8.97 \%\end{array}$ \\
\hline $\begin{array}{c}\text { Net- } \\
\text { banking }\end{array}$ & $\begin{array}{l}\text { Yes } \\
\text { No }\end{array}$ & $\begin{array}{c}56 \\
189\end{array}$ & $\begin{array}{l}22.85 \% \\
77.14 \%\end{array}$ \\
\hline $\begin{array}{c}\text { Reason } \\
\text { for } \\
\text { choosing a } \\
\text { Bank }\end{array}$ & $\begin{array}{l}\text { No Specific reason } \\
\text { Opened by employer } \\
\text { For the sake of net- } \\
\text { banking } \\
\text { Nearby and easy to } \\
\text { access } \\
\text { Offer better customer } \\
\text { service }\end{array}$ & $\begin{array}{c}60 \\
8 \\
13 \\
\\
41 \\
\\
\\
123\end{array}$ & $\begin{array}{c}24.48 \% \\
3.26 \% \\
5.30 \% \\
16.73 \% \\
50.20 \%\end{array}$ \\
\hline
\end{tabular}

Graph One: Showing top reasons for using net-banking technology

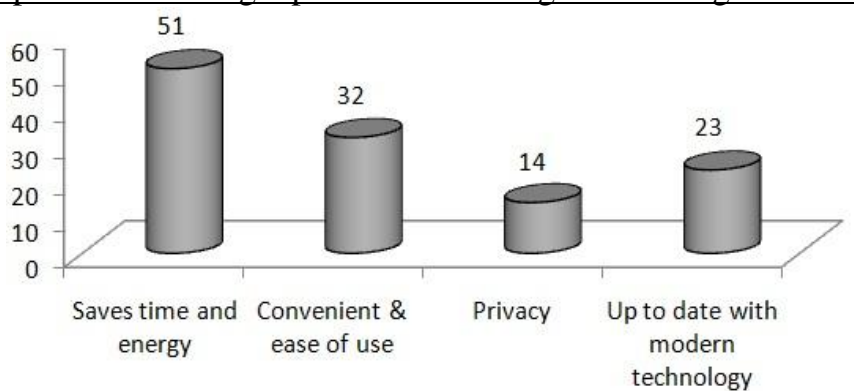

The top priority for using net-banking technology is to save time followed by convenience. The identified third priority for using the net-banking is to be up to date with modern technology. Some people also felt that net-banking gives them enough privacy to do banking.

Those who use net-banking services use it mainly for checking the balance followed by online payments, various purchases, fund transfers and account statement downloading. They also use minimally for checking their loan status and credit card related issues.

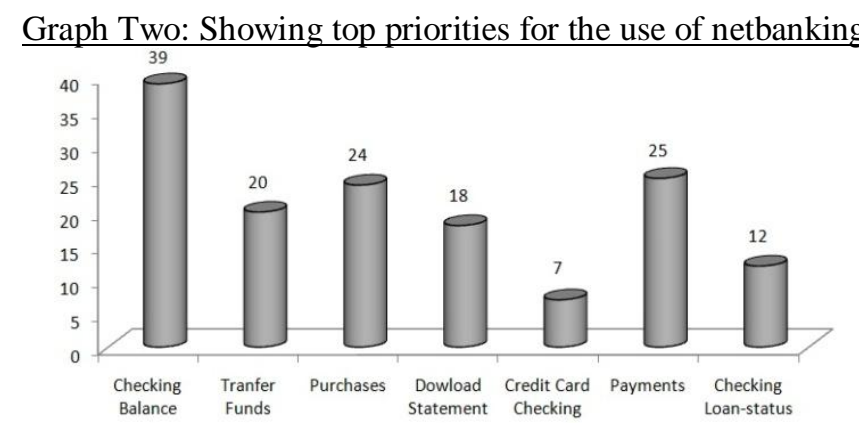

Those who do not use net-banking technology have the following reasons. Majority of the subjects claim that they are not familiar with the technology. They also claim that they do not venture into this technology because of less transaction. Some do not use net-banking due to lack of computer facilities at home or at their workplaces. Some of the subjects believe that online transactions are not reliable and their personal information could be stolen. Few others also feel that online banking is complicated and time consuming; and yet others mentioned that their bank has no good online banking facilities. 
Graph Three: Showing major reasons for non-usage of net-banking

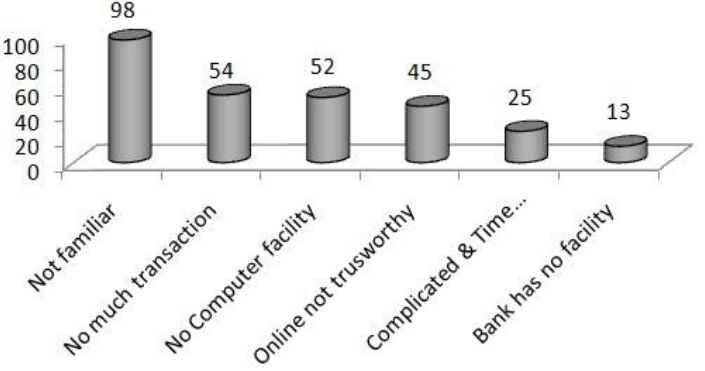

V. Discussion:

The results of the study confirm the view of psychologists that the middle aged people are set in their way of life, leading to innovation resistance rather than technology adaptation. As the subjects have pointed out, the top reason for using net-banking is to save time and energy as well as doing banking works at their own convenient place and time. Therefore these innovations in the banking sector are good for the consumer and they are improvements over existing practices.

The study results reveal that the intention to use net-banking is mainly due to the perceived usefulness that is the degree to which a person believes that using a particular banking system would enhance his or her task performance (may be save time, convenient to do banking anywhere and anytime) and also perceived ease-of-use that is, the degree to which a person believes that using a particular system would be free from effort (saving energy and the hardship of visiting crowded banks). However, the majority of the subjects of the study resist the new technology for various reasons. In spite of the fact that computer technology has become popular in every sphere of life today, more than $75 \%$ of the subjects studied claim that they are not familiar with the modern technology. This reveals further their resistance and the preference for existing, familiar mode of behavior and doing things over novel ones. The research identifies the following reasons for innovation resistances among the middle aged people.

a) Not familiar with the modern technology

b) Do not have much transaction to do net-banking

c) Using net-banking is complicated and time consuming

d) It is not safe to do net-banking

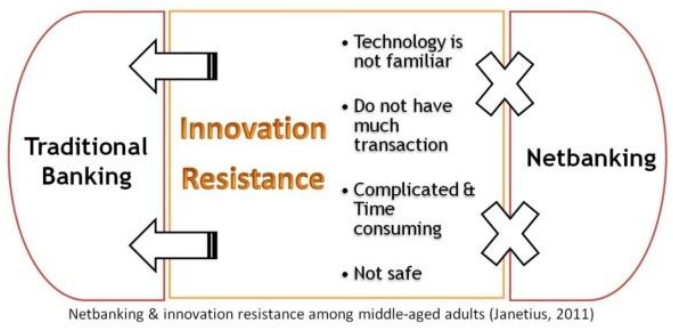

On the basis of these reasons for resistance, few myths and irrational thinking could be identified as they are conceived and revealed by the middle aged adults of this study, ultimately leading to resistance to innovation and the use of modern technology.

1) Net-banking is for the people who have lots of money and do daily transactions - This is not true as we can venture into net-banking even if we have a single transaction in a month.

2) Net-banking is complicated and time consuming - This is also not true as many of the net-banking middle aged people have identified 'time saving' as the major reason for using this technology.

3) Net-banking is not safe and personal information can be stolen by anybody - This also shows the avoidance of risk taking behavior among the middle aged people leading to the false belief. Certain amount of risk is there if one uses public computers at browsing centers. However, as per the directions of the bank, if proper precautions are taken by the individual customers, like changing the password regularly, using a password with alpha-numerical characters, fraudulent malicious cybercrimes could be reduced to minimal.

\section{Conclusions:}

The study was conducted to identify the net-banking behavior of middle aged adults in and around Pollachi region in Tamil Nadu. The study has identified that nearly $77 \%$ of the people being studied do not use net banking. More than technology adaptation, innovation resistance is seen among middle aged adults. Based on the study the following recommendations are put forward for banks for a more usable online banking among 
middle age adults. There is a need to highlight the usefulness and ease of use for making better awareness among people on net-banking so that many more middle age adults would opt for net-banking facilities in the future.

\section{References}

[1] Arnould, E., 1. Price, \& Zinkhan, G. (2004). Consumers. Boston: McGraw- Hill/Irwin

[2] Corey, G. (1986). I never knew I had a choice (3rd ed.) NY: Brooks/Cole Publishing Company

[3] Fadul, J. (2010). The EPIC Generation: Experiential, Participative, Image-Driven, Connected. Manila: Lulu Press

[4] Gardener, E. P., Molyneux, Moore, \&. Winters. (1999). The Impact of the Single Market Programme on EU Banking. Boston: Kluwer Academic Press

[5] Janetius, S. T. (2012). Abyssinia in the new millennium - Culture and Higher Education in Ethiopia. Thrissur: Mishil \& Js Publishers (in press)

[6] Levinson, D. (1978). The seasons of a man's life. New York: Knopf

[7] Ram, S. \& Sheth, J. N. (1989). Consumer resistance to innovations: the marketing problem and its solutions. The Journal of Consumer Marketing, 6 (2), 5-14

[8] Venkatesh, V. \& Davis, F. D. (2000), "A theoretical extension of the technology acceptance model: Four longitudinal field studies", Management Science 46(2): 186-204 